\title{
WASTE MINERAL POWDERS AS A COMPONENTS OF POLYMER-CEMENT COMPOSITES
}

\author{
B. JAWORSKA ${ }^{1}$, J. J. SOKOLOWSKA ${ }^{2}$, P. LUKOWSKI ${ }^{3}$, J. JAWORSKI ${ }^{4}$
}

The introduction of the sustainable development elements in the construction industry leads to finding new ways of using waste minerals that are difficult in storage and recycling. Coal combustion products have been already introduced into building materials as a part of cement or concrete but they have been thought insufficiently compatible with the polymer-cement binders [7]. The paper presents results of the mechanical properties of polymer-cement composites containing two types of mineral additives: waste perlite powder that is generated during the perlite expanding process, and calcium fly ash which is the byproduct of burning coal in conventional furnaces. Mechanical tests of polymer-cement composites modified with wastes were carried out after 28 and 90 days of curing. As a part of preliminary study specific surface area and particle size distribution of mineral wastes were determined.

Keywords: polymer-cement composites (PCC), waste perlite powder, calcium fly ash, sustainable development

\section{INTRODUCTION}

The worldwide development of building industry is associated with concrete production, where the greenhouse gas emission is unavoidable. However, the implementation of the sustainable development strategy principles [3] leads to a low-carbon economy introduction. It is possible,

\footnotetext{
${ }^{1}$ MSc., Warsaw University of Technology, Faculty of Civil Engineering, Al. Armii Ludowej 16, 00-637 Warsaw, Poland, e-mail: b.jaworska@il.pw.edu.pl

${ }^{2}$ DSc., Warsaw University of Technology, Faculty of Civil Engineering, Al. Armii Ludowej 16, 00-637 Warsaw, Poland, e-mail: j.sokolowska@il.pw.edu.pl

${ }^{3}$ Prof., Warsaw University of Technology, Faculty of Civil Engineering, Al. Armii Ludowej 16, 00-637 Warsaw, Poland, e-mail: p.lukowski@il.pw.edu.pl

${ }^{4}$ MSc., Warsaw University of Technology, Faculty of Civil Engineering, Al. Armii Ludowej 16, 00-637 Warsaw, Poland, e-mail: j.jaworski2@il.pw.edu.pl
} 
thanks to the use of energy industry combustion by products to reduce greenhouse gas emission associated with cement and concrete production. The continual demand for electricity leads to an increased consumption of coal and thus to production of large amounts of combustion byproducts such as calcium fly ash [4]. Storing of wastes in landfills can be cumbersome for the environment, and since fly ashes have proved to be a valuable resource from the sustainable development point of view, their application in building materials is completely justified. However, unfavorable morphology of wastes [5] may cause difficulties when it comes to application in polymer-cement composites. Another difficult to store and recycle waste material is perlite powder, the byproduct formed during the expanded perlite production process. The expanded perlite has found many applications and thus a large amount of byproduct is produced. Besides the construction applications, one of many expanded perlite use is e.g. horticulture [2]. However, when it comes to building materials engineering, its ability to absorb water is a disadvantage, because it means increased water demand. Despite these problems, increased production of industrial waste leads to seeking of new material solutions and new ways of waste disposal.

\section{EXPERIMENTAL}

\subsection{SCOPE OF THE RESEARCH PROGRAM}

The research program was designed to assess the impact of waste mineral powders content on the mechanical properties of polymer-cement composites. Mixtures were designed with the following assumptions:

- dosage levels of waste powders: $5 \%, 10 \%, 15 \%, 20 \%, 25 \%$ of cement mass,

- constant polymer content: $20 \%$ of cement mass,

- constant level of water-cement ratio of 0.5 .

Modified polymer-cement mortars were prepared using Portland cement CEM I 42.5, standard sand fulfilling requirements of PN-EN 196-1 [8], an aqueous dispersion of styrene-acrylic copolymer, calcium fly ash from one of the Polish power plants and waste perlite powder from expanded perlite factory. The reference material used in this investigation was standard cement mortar. 


\subsection{TEST PROCEDURE}

Polymer-cement composites were tested after 28 and 90 days of curing in mixed wet conditions. During the first day specimens were tightly covered with polyethylene sheets and, after disbandment, immersed for five days in water at $20-22^{\circ} \mathrm{C}$, then, until testing, held in air-dry conditions (temperature of $20-22^{\circ} \mathrm{C}$, relative humidity of $60 \pm 5^{\circ} \mathrm{C}$ ) to provide adequate conditions for the hydration of cement binder as well as the formation of a continuous polymer film. Standard mortars were stored in wet conditions as recommended in PN-EN 196-1. As a part of preliminary study, the specific surface area and particles size distribution of mineral wastes were tested using laser analyzer.

\subsection{SPECIFIC SURFACE AREA AND PARTICLES SIZE DISTRIBUTION}

Specific surface area, relative frequency and cumulative frequency of mineral waste powders grains size distribution were tested by Horriba L300 laser analyzer (using the Laser Scattering Method [1]). Parameters of measurement were as follows: index of refraction - 1.16-0.00i, circulation pump speed of 7.0, duration of the ultrasounds emission - 1 min. Tested materials were dispersed in a sodium polimetaphosphate water solution. Cumulative frequency plots of size distribution curves for two tested waste mineral powders are presented in Fig. 1. For each waste powder, three samples were subsequently tested. The obtained results were compared with data obtained for metakaolin, one of the most effective mineral additives for concrete. Waste perlite powder particle diameters did not exceed $100 \mu \mathrm{m}$, as it was in the case of calcium fly ash. All of the mineral additives contained particles smaller than $4 \mu \mathrm{m}$ (Fig. 1) and similar content of particles smaller than $45 \mu \mathrm{m}$ (for perlite powder - 97\%, calcium fly ash - 89\% and metakaolin - 99\%). Only the calcium fly ash contains particles bigger than $67 \mu \mathrm{m}$. Average size of perlite powder particle was about $19 \mu \mathrm{m}$ whereas for fly ash it was nearly $25 \mu \mathrm{m}$ - larger than in the case of metakaolin (Table 1). Waste perlite powders particles are of similar average diameter to metakaolin but of nearly 5 times smaller specific surface area. Those differences in diameter and specific surface area cause various curves shape. Both waste mineral powders having a small average particle diameter may act as filler, which fills voids between particles of cement. However, increased porosity of waste perlite powder particles [6] results in an increased water demand and deterioration of mix consistency. And in case of calcium fly ash on the deterioration of the mix workability may affect particles higher than $45 \mu \mathrm{m}$. 


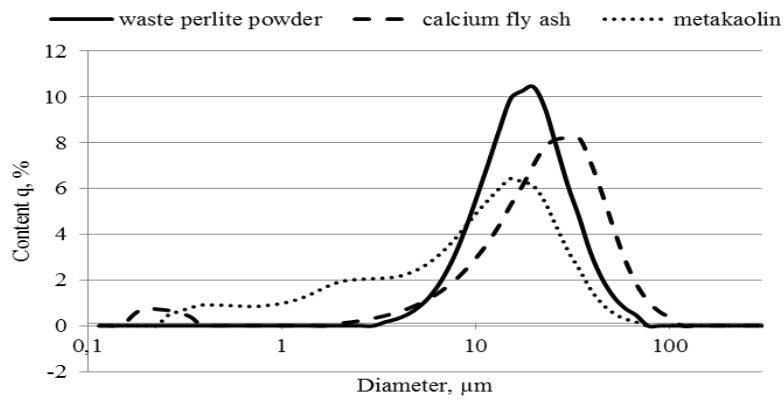

Fig. 1. Grain size distribution curves for tested mineral additives (relative distribution)

Table 1. Specific surface area and particle average diameters of mineral additives

\begin{tabular}{|c|c|c|c|}
\hline No & Mineral additive & Specific surface area, $\mathrm{cm}^{2} / \mathrm{cm}^{3}$ & Average diameter, $\mu \mathrm{m}$ \\
\hline 1 & waste perlite powder & 4237 & 18.69 \\
\hline 2 & calcium fly ash & 13677 & 24.91 \\
\hline 3 & metakaolin & 21052 & 11.94 \\
\hline
\end{tabular}

\subsection{MECHANICAL PROPERTIES OF MODIFIED POLYMER-CEMENT COMPOSITES}

Flexural and compressive strength of polymer-cement composites modified with mineral wastes were tested after 28 and 90 days of curing. The investigation was carried out for composites modified with $20 \%$ content of polymer and $5 \%$ to $25 \%$ content of waste minerals (of cement mass). Flexural and compressive strength tests were performed in accordance with PN-EN 196-1 using testing machine INSTRON 567.

\subsubsection{FLEXURAL STRENGTH OF MODIFIED POLYMER-CEMENT COMPOSITES}

Flexural strength results of polymer-cement composites after 28 days of curing are presented in Fig. 2. First loss of strength occurs after adding of $5 \%$ of wastes. For composites containing calcium fly ash, increasing the amount up to $15 \%$ resulted in a further strength reduction. In the case of composites modified with waste perlite powder first loss of strength of up to $10 \%$ content of additive and another one after adding of $25 \%$ of waste. Compared to unmodified polymer cementcomposites, flexural strength of composites with $25 \%$ content of waste minerals decreased by $17 \%$ and $33 \%$ for calcium fly ash and waste perlite powder, respectively. Flexural strength change for composites modified with up to $20 \%$ content of those waste mineral powders is similar. 


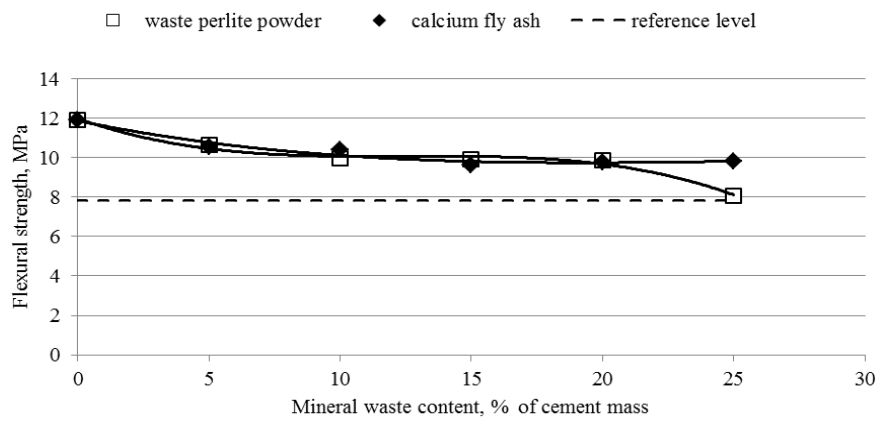

Fig. 2. Flexural strength for polymer-cement composites with $20 \%$ polymer content in function of waste mineral powder content (after 28 days of curing) compared to the standard cement mortar (no mineral waste) - reference level

Flexural strength results of polymer-cement composites after 90 days of curing are presented in Fig. 3. The contents of mineral wastes had a similar effect on the samples tested after long period of curing. First deterioration of composite's properties was observed after adding $5 \%$ of wastes, and then up to $20 \%$ content of powders resulted in similar flexural strength changes. Increasing calcium fly ash content up to $25 \%$ did not have an effect on further strength deterioration as much as it was observed for polymer-cement composites containing waste perlite powder. Compared to unmodified polymer cement-composites, flexural strength of composites with $25 \%$ content of waste minerals decreased by $8 \%$ and $29 \%$ for calcium fly ash and waste perlite powder, respectively.

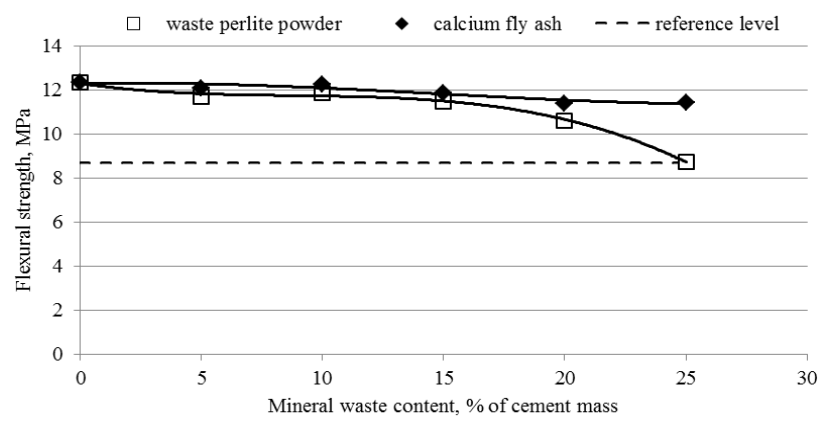

Fig. 3. Flexural strength for polymer-cement composites with $20 \%$ polymer content in function of waste mineral powder content (after 90 days of curing) compared to the standard cement mortar (no mineral waste) - reference level 
Flexural strength of tested composites after 28 days of curing is within the range 8.0-10.7 MPa and 9.8-10.6 MPa for composites with waste perlite powder and calcium fly ash, respectively, and after 90 days of curing is $8.6-11.7 \mathrm{MPa}$ and 11.4-12.1 MPa. For standard cement mortar it is $7.8 \mathrm{MPa}$ after 28 days and $8.7 \mathrm{MPa}$ after 90 days. It means that all of the 28-days tested modified polymercement composites has better flexural strength, compared to cement binder, and after 90 days, only mortar with $25 \%$ waste perlite powder was slightly weaker. Relations shown in Fig. 2 and Fig. 3 can be approximated by polynomials of the third degree (second degree in the case of composites with calcium fly ash after 28 days curing). Solution of linear equations allows determining the inflection point of the graph and thus estimating the optimum value of wastes at which the change in the strength of the composite is made. Approximation results are shown in Table 2.

Table 2. Estimation of optimal mineral waste content in polymer-cement composite - impact on flexural strength

\begin{tabular}{|c|c|c|c|c|c|}
\hline Additive & $\begin{array}{c}\text { Curing } \\
\text { day }\end{array}$ & Approximating function & $\begin{array}{c}\text { Coefficient of } \\
\text { determination, } \mathrm{R}^{2}\end{array}$ & Optimum content, \% & $\begin{array}{c}\text { Calculated } \\
\text { flexural } \\
\text { strength, MPa }\end{array}$ \\
\hline \multirow{2}{*}{$\begin{array}{c}\text { calcium } \\
\text { fly ash }\end{array}$} & 28 & $\begin{array}{r}\mathrm{f}_{\mathrm{b}}=0.0059 \mathrm{~m} / \mathrm{c}^{2}-0.2258 \mathrm{~m} / \mathrm{c}+ \\
11.82\end{array}$ & 0.95 & 19.1 & 9.7 \\
\cline { 2 - 6 } & 90 & $\begin{array}{c}\mathrm{f}_{\mathrm{b}}=0.0001 \mathrm{~m} / \mathrm{c}^{3}-0.0055 \mathrm{~m} / \mathrm{c}^{2} \\
+0.0231 \mathrm{~m} / \mathrm{c}+12.281\end{array}$ & 0.89 & 18.3 & 11.5 \\
\hline \multirow{2}{*}{$\begin{array}{c}\text { waste } \\
\text { perlite } \\
\text { powder }\end{array}$} & 28 & $\begin{array}{c}\mathrm{f} \mathrm{b}=-0.001 \mathrm{~m} / \mathrm{c}^{3}+0.0384 \mathrm{~m} / \mathrm{c}^{2}- \\
0.4737 \mathrm{~m} / \mathrm{c}+11.991\end{array}$ & 0.98 & 12.8 & 10.1 \\
\cline { 2 - 6 } & 90 & $\begin{array}{c}\mathrm{f}_{\mathrm{b}}=-0.0006 \mathrm{~m} / \mathrm{c}^{3}+0.017 \mathrm{~m} / \mathrm{c}^{2}- \\
0.1621 \mathrm{~m} / \mathrm{c}+12.298\end{array}$ & 0.99 & 9.4 & 11.8 \\
\hline
\end{tabular}

\subsubsection{COMPRESSIVE STRENGTH OF MODIFIED POLYMER-CEMENT COMPOSITES}

Compressive strength results of polymer-cement composites after 28 days of curing are presented in Fig. 4. First loss of strength occurs after addition of $5 \%$ of wastes. For composites containing calcium fly ash increasing the amount of up to $15 \%$ and then up to $25 \%$ resulted in further slight strength reductions. In the case of composites modified with waste perlite powder first loss of strength is up to $5 \%$ content of additive and another one after addition of $15 \%$ of waste. Compared to unmodified polymer cement-composites, compressive strength of composites with $25 \%$ content of waste minerals decreased by $20 \%$ and $41 \%$ for calcium fly ash and waste perlite powder, respectively. 
Compressive strength results of polymer-cement composites after 90 days of curing are presented in Fig. 5. The contents of mineral wastes had a similar effect on the samples tested after long period of curing. First deterioration of composites properties was observed after addition of $5 \%$ of wastes, and then after $15 \%$ content of powders compressive strength change was similar. Increasing calcium fly ash content up to $25 \%$ resulted in a further slight strength reduction. More significant strength deterioration was observed for polymer-cement composites containing waste perlite powder. Compared to unmodified polymer cement-composites, compressive strength of composites containing $25 \%$ of waste minerals decreased by $15 \%$ and $34 \%$ for calcium fly ash and waste perlite powder, respectively.

Compressive strength of tested composites after 28 days of curing is in range 26.5-37.4 MPa and 35.1-39.5 MPa for composites with waste perlite powder and calcium fly ash, respectively, and after 90 days of curing is $30.9-42.5 \mathrm{MPa}$ and $40.2-46.2 \mathrm{MPa}$. For standard cement mortar it is $48.3 \mathrm{MPa}$ after 28 days and $57.6 \mathrm{MPa}$ after 90 days. None of the tested modified polymer-cement composites had better compressive strength, compared to cement binder. This is due to worse mechanical properties of polymer itself rather than the impact of wastes.

Statistical analysis of impact of wastes on the compressive strength of composites shows that this relationship can be approximated by a third order polynomial (Table 3).

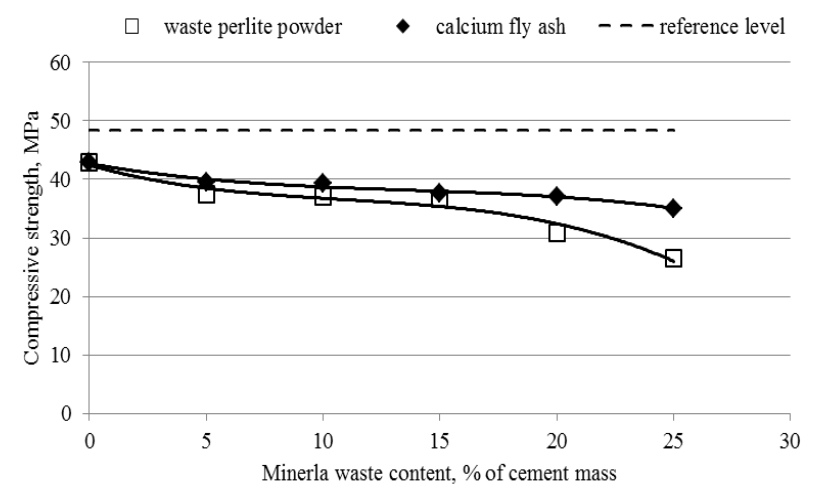

Fig. 4. Compressive strength for polymer-cement composites with $20 \%$ polymer content in function of waste mineral powder content (after 28 days of curing) compared to the standard cement mortar (no mineral waste) - reference level 


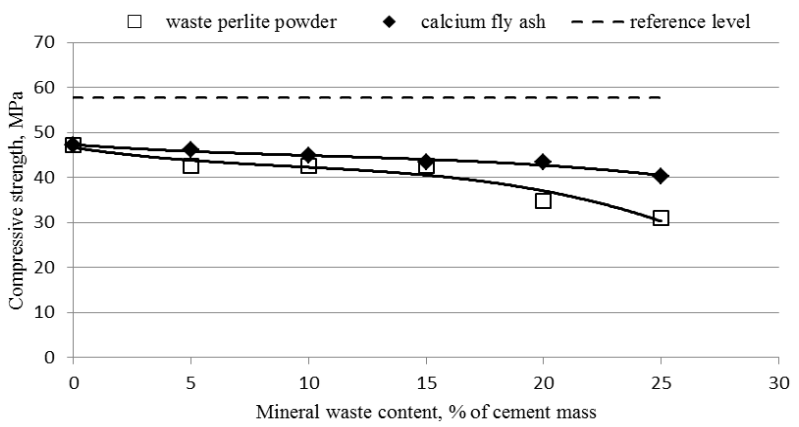

Fig. 5. Compressive strength for polymer-cement composites with $20 \%$ polymer content in function of waste mineral powder (after 90 days of curing) compared to the standard cement mortar (no mineral waste) - reference level

Table 3. Estimation of optimal mineral waste content in polymer-cement composite - impact on compressive strength

\begin{tabular}{|c|c|c|c|c|c|}
\hline Additive & $\begin{array}{c}\text { Curing } \\
\text { day }\end{array}$ & Approximating function & $\begin{array}{c}\text { Coefficient of } \\
\text { determination, } \mathrm{R}^{2}\end{array}$ & $\begin{array}{c}\text { Optimum content, } \\
\%\end{array}$ & $\begin{array}{c}\text { Calculated } \\
\text { compressive } \\
\text { strength, MPa }\end{array}$ \\
\hline \multirow{2}{*}{$\begin{array}{c}\text { calcium } \\
\text { fly ash }\end{array}$} & 28 & $\begin{array}{c}\mathrm{f}_{\mathrm{c}}=-0.001 \mathrm{~m} / \mathrm{c}^{3}+0.0424 \mathrm{~m} / \mathrm{c}^{2} \\
-0.7181 \mathrm{~m} / \mathrm{c}+42.681\end{array}$ & 0.98 & 14.1 & 38.2 \\
\cline { 2 - 6 } & 90 & $\begin{array}{c}\mathrm{f}_{\mathrm{c}}=-0.0007 \mathrm{~m} / \mathrm{c}^{3}+0.0216 \\
\mathrm{~m} / \mathrm{c}^{2}-0.3903 \mathrm{~m} / \mathrm{c}+47.27\end{array}$ & 0.96 & 10.2 & 44.8 \\
\hline \multirow{2}{*}{$\begin{array}{c}\text { waste } \\
\text { perlite } \\
\text { powder }\end{array}$} & 28 & $\begin{array}{c}\mathrm{f}_{\mathrm{c}}=-0.0025 \mathrm{~m} / \mathrm{c}^{3}+0.0827 \\
\mathrm{~m} / \mathrm{c}^{2}-1.1436 \mathrm{~m} / \mathrm{c}+42.438\end{array}$ & 0.96 & 11.0 & 36.5 \\
\cline { 2 - 6 } & 90 & $\begin{array}{c}\mathrm{f}_{\mathrm{c}}=-0.002 \mathrm{~m} / \mathrm{c}^{3}+0.0565 \mathrm{~m} / \mathrm{c}^{2} \\
-0.8003 \mathrm{~m} / \mathrm{c}+46.625\end{array}$ & 0.93 & 9.4 & 42.4 \\
\hline
\end{tabular}

In the case of mineral wastes impact on compressive strength of polymer-cement composites the optimum content is in range $10.2-14.1 \%$ for calcium fly ash and $9.4-11.0 \%$ for waste perlite powder.

\section{CONCLUSION}

The research results proved that selected industrial wastes - calcium fly ash and waste perlite powder affect the mechanical properties of polymer-cement composites. Both additives had negative impact on the flexural and compressive strength of the polymer-cement composite, however this impact is not very significant. In the worst case, the substitution of $25 \%$ of cement mass by waste perlite powder caused $33 \%$ decrease of flexural strength and $41 \%$ decrease of 
compressive strength of 28-days-old composites. Less deterioration was observed in the case of specimens with calcium fly ash (respectively: $17 \%$ and $20 \%$ ) which may be due to better morphology of fly ash, compared to waste perlite powder. Polymer-cement composites modified with waste powders have lower values of compressive strength, but higher (or similar) values of flexural strength, as compared to the standard cement mortar. Statistical analysis of preliminary studies on the effects of waste on selected mechanical properties of polymer-cement composites showed that in the case of waste perlite powder the optimum content is $9.4 \%$ of the cement mass. When it comes to calcium fly ash, the optimum content is in the range of $10-14 \%$ of the cement mass. Studies have proved the possibility of use both mineral wastes as components of polymercement mortars.

\section{Acknowledgments}

This paper was realized in the framework of Applied Research Program No. PBS1/A5/14/2012 of the National Centre for Research and Development.

\section{REFERENCES}

1. C. F. Bohren, D. R. Huffmann, "Absorption and scattering of light by small particles", New York: Wiley Interscience, 2010

2. P. A. Ciullo, "Industrial Minerals and Their Uses", Noyes Publications, 580, 1996.

3. L. Czarnecki, M. Kaproń, „Definiowanie zrównoważonego budownictwa”, Materiały Budowlane, 1, 69-71, 2010.

4. Z. Giergiczny, „Popiół lotny w składzie cementu i betonu.”, Wydawnictwo Politechniki Śląskiej, Monografia nr 509, Gliwice, 2013.

5. Z. Giergiczny, „Rola popiołów lotnych wapniowych i krzemionkowych w kształtowaniu właściwości współczesnych spoiw budowlanych i tworzyw cementowych.”, Wydawnictwo Politechniki Krakowskiej, Seria: Inżynieria Lądowa, Monografia nr 325, Kraków, 2006.

6. P. Łukowski, J. J. Sokołowska, G. Adamczewski, B. Jaworska, "Waste perlite powder as the potential microfiller of polymer composites.", Mechanics and Materials (Jemioło S. and Lutomirska M. eds.), Oficyna Wydawnicza Politechniki Warszawskiej, 193-200, 2013.

7. M. Ozkul, "Effect of aggregate on the properties of epoxy concrete.", $8^{\text {th }}$ International Congress on Polymers in Concrete, Oostende, 193-198, 1995.

8. PN-EN 196-1: Methods of testing cement. Determination of strength. 


\section{LIST OF FIGURES AND TABLES:}

Fig. 1. Grain size distribution curves for tested mineral additives (relative distribution)

Rys. 1. Krzywe granulometryczne badanych dodatków mineralnych

Fig. 2. Flexural strength for polymer-cement composites with $20 \%$ polymer content in function of waste mineral powder content (after 28 days of curing) compared to the standard cement mortar (no mineral waste) - reference level

Rys. 2. Wytrzymałość na zginanie PCC, zawierających $20 \%$ polimeru, modyfikowanych mineralnymi pyłami odpadowymi po 28 dniach dojrzewania (poziom odniesienia - zaprawa normowa)

Fig. 3. Flexural strength for polymer-cement composites with $20 \%$ polymer content in function of waste mineral powder (after 90 days of curing) compared to the standard cement mortar (no mineral waste) reference level

Rys. 3. Wytrzymałość na zginanie PCC, zawierających $20 \%$ polimeru, modyfikowanych mineralnymi pyłami odpadowymi po 90 dniach dojrzewania (poziom odniesienia - zaprawa normowa)

Fig. 4. Compressive strength for polymer-cement composites with $20 \%$ polymer content in function of waste mineral powder (after 28 days of curing) compared to the standard cement mortar (no mineral waste) reference level

Rys. 4. Wytrzymałość na ściskanie PCC, zawierających $20 \%$ polimeru, modyfikowanych mineralnymi pyłami odpadowymi po 28 dniach dojrzewania (poziom odniesienia - zaprawa normowa)

Fig. 5. Compressive strength for polymer-cement composites with $20 \%$ polymer content in function of waste mineral powder (after 90 days of curing) compared to the standard cement mortar (no mineral waste) reference level

Rys. 5. Wytrzymałość na ściskanie PCC, zawierających 20\% polimeru, modyfikowanych mineralnymi pyłami odpadowymi po 90 dniach dojrzewania (poziom odniesienia - zaprawa normowa)

Tab. 1. Specific surface area and particle average diameters of mineral additives

Tab. 1. Wyniki oznaczeń powierzchni właściwej i rozkładu uziarnienia dodatków mineralnych

Tab. 2. Estimation of optimal mineral waste content in polymer-cement composites - impact on flexural strength

Tab. 2. Oszacowanie optymalnej zawartości odpadów mineralnych w kompozytach polimerowocementowych - wpływ na wytrzymałość na zginanie

Tab. 3. Estimation of optimal mineral waste content in polymer-cement composites - impact on compressive strength

Tab. 3. Oszacowanie optymalnej zawartości odpadów mineralnych w kompozytach polimerowocementowych - wpływ na wytrzymałość na ściskanie 


\section{ODPADOWE PYLY MINERALNE JAKO SKLADNIKI KOMPOZYTÓW POLIMEROWO-CEMENTOWYCH}

Słowa kluczowe: kompozyty polimerowo-cementowe, odpadowy pył perlitowy, popiół lotny wapienny, zrównoważony rozwój

\section{STRESZCZENIE:}

Przedmiotem badań było określenie wpływu zawartości odpadowych pyłów mineralnych na wybrane właściwości mechaniczne kompozytów polimerowo-cementowych. Szukanie nowych sposobów na zagospodarowanie odpadów mineralnych stanowi element strategii zrównoważonego rozwoju w budownictwie. Wprowadzenie odpadów przemysłowych do materiałów budowlanych pozwala zmniejszyć emisję gazów cieplarnianych wydzielających się podczas produkcji cementu czy betonu. Jako przedmiot badań przyjęto polimerowo-cementowe zaprawy, zawierające kopolimer styrenowo-akrylowy, modyfikowane odpadowym pyłem perlitowym (uboczny produkt procesu ekspandacji perlitu), oraz produktem ubocznym spalania węgla brunatnego, popiołem lotnym wapiennym. Zawartość odpadowych pyłów mineralnych zmieniała się w przedziale 5-25\% masy cementu. Badano wytrzymałość na zginanie i ściskanie zapraw po 28 i 90 dniach dojrzewania próbek w warunkach mieszanych, wodno-powietrznych. Zastosowano taki sposób przechowywania próbek, aby zapewnić odpowiednie warunki dla hydratacji cementu (warunki mokre), przy jednoczesnych odpowiednich warunkach do uformowania ciągłej błony polimerowej (warunki suche). Zbadano również powierzchnię właściwą i uziarnienie wybranych dodatków mineralnych. Wyniki badań granulometrycznych dla popiołu lotnego wapiennego oraz odpadowego pyłu perlitowego porównano z wynikami dla metakaolinitu, jednego z najefektowniejszych dodatków mineralnych do betonu. Analiza granulometryczna wykazała, że największymi rozmiarami ziaren charakteryzował się popiół lotny wapienny, który jako jedyny posiadał ziarna przekraczające $67 \mu \mathrm{m}$. Odpadowy pył perlitowy charakteryzowały ziarna o średnim rozmiarze zbliżonym do rozmiaru ziaren metakaolinitu, ale ich powierzchnia właściwa była prawie 5 razy mniejsza. Wszystkie badane dodatki mineralne posiadały ziarna o średnicy z przedziału $4 \mu \mathrm{m} \div 45 \mu \mathrm{m}$ (Rys. 1), przez co spełniają rolę mikrowypełniacza pustych przestrzeni między ziarnami cementu, jednak zwiększona porowatość odpadowego pyłu perlitowego, czy występowanie ziaren popiołu lotnego wapiennego o rozmiarach większych od $45 \mu \mathrm{m}$, wpływają na pogorszenie urabialności mieszanek polimerowocementowych.

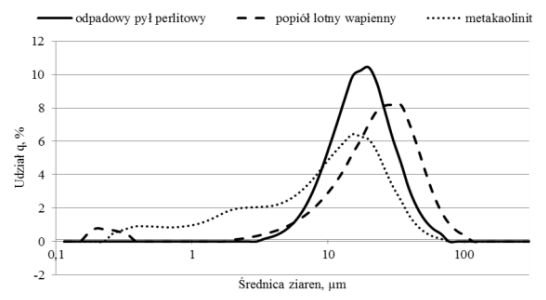

Rys. 1. Krzywe granulometryczne badanych dodatków mineralnych

Wartości wytrzymałości na zginanie kompozytów polimerowo-cementowych modyfikowanych odpadami mineralnymi zarówno po 28 dniach dojrzewania, jak i po 90 dniach, przyjmowały wyższe wartości od zaprawy normowej, niemniej zaobserwowano obniżenie wytrzymałości kompozytów już po dodaniu 5\% odpadów. Dalsze zwiększanie zawartości odpadowych pyłów mineralnych nie wpłynęło znacząco na wytrzymałość na zginanie kompozytów polimerowocementowych. Wyjątek stanowi 25\% (względem masy cementu) zawartość odpadowego pyłu perlitowego, która 
spowodowała obniżenie wytrzymałości na zginanie zawierających ten odpad kompozytów, osiągając tym samym wartości zbliżone do wytrzymałości na zginanie zaprawy normowej (Rys. 2). W przypadku wytrzymałości na ściskanie, wszystkie modyfikowane odpadami kompozyty polimerowo-cementowe przyjmowały niższe wartości wytrzymałości w porównaniu do zaprawy normowej. Większy wpływ na wytrzymałość na ściskanie zaobserwowano dla kompozytów modyfikowanych odpadowym pyłem perlitowym (Rys. 3).

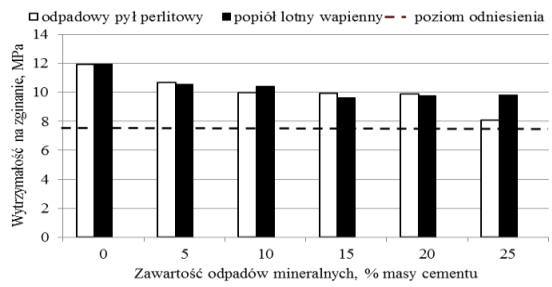

Rys. 2. Wytrzymałość na zginanie kompozytów polimerowo-cementowych, zawierających $20 \%$ polimeru, modyfikowanych mineralnymi pyłami odpadowymi po 28 dniach dojrzewania (porównane z zaprawą normową niemodyfikowaną odpadami mineralnymi - poziom odniesienia)

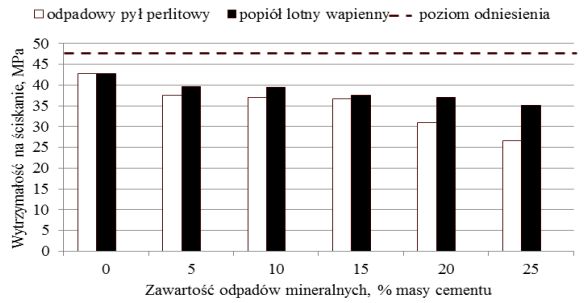

Rys. 3. Wytrzymałość na ściskanie kompozytów polimerowo-cementowych, zawierających 20\% polimeru, modyfikowanych mineralnymi pyłami odpadowymi po 28 dniach dojrzewania (porównane z zaprawą normową niemodyfikowaną odpadami mineralnymi - poziom odniesienia)

W najgorszym przypadku, zastąpienie $25 \%$ cementu odpadowym pyłem perlitowym spowodowało $33 \%$ spadek wytrzymałości na zginanie i $41 \%$ spadek wytrzymałości na ściskanie kompozytów badanych po 28 dniach. Mniejsze pogorszenie odnotowano w przypadku kompozytów zawierających popiół lotny wapienny (odpowiednio 17\% i 20\%), co może być spowodowane lepszą morfologią popiołów lotnych, w porównaniu do odpadowego pyłu perlitowego. Zaprojektowane kompozyty, zawierające do $25 \%$ odpadów mineralnych, charakteryzowały się niższymi wartościami wytrzymałości na ściskanie, ale za to większymi (lub zbliżonymi - 25\% odpadowego pyłu perlitowego) wartościami wytrzymałości na zginanie, w porównaniu do zaprawy normowej. Analiza statystyczna przeprowadzonych badań pozwoliła na określenie optymalnej ilości odpadowego pyłu perlitowego, oraz przedziału zawartości dla popiołu lotnego wapiennego. Na podstawie uzyskanych wyników stwierdzono, że możliwe jest racjonalne zastosowanie odpadowego pyłu perlitowego i popiołu lotnego wapiennego, jako składników budowlanych kompozytów polimerowocementowych. 